\title{
Innovation and stock markets: International evidence on manufacturing and services
}

\author{
Oxford University Centre for the Environment Working Paper, number tba
}

\author{
Dariusz Wójcik \\ School of Geography and St. Peter's College, Oxford \\ dariusz.wojcik@spc.ox.ac.uk \\ Draft, September 2008
}

\begin{abstract}
The paper investigates the link between stock markets and innovation, by focusing on the relationship between firms' innovativeness and their participation in public stock markets. It reviews theoretical and empirical literature on capital structure and goingpublic decision, combined with insights from innovation studies, to argue that there are no reasons, why a positive relationship between innovativeness and stock market participation should not apply to both manufacturing and services firms. This hypothesis is confirmed through the analysis of data from 30 European countries, as well as the USA and Japan, which shows that the positive relationship between innovativeness and stock market participation is actually stronger for services than for manufacturing firms. It is also shown that the relationship differs between countries as a reflection of their diverse institutions. It is weak or absent in countries where institutional environment of stock markets is weak, e.g. transition economies or Italy, and pronounced where institutions are particularly stock market friendly e.g. the USA and the UK. Finally, the paper shows that while the Internet boom brought hoards of innovative firms to stock markets, the positive relationship between innovativeness and stock market participation is likely to have existed before. Implications are drawn for research on the impact of financial structure on innovation and growth.
\end{abstract}

Keywords: innovation, stock market, equity, institutions, services, Internet boom

JEL codes: G0, 00

\section{Introduction}

This paper investigates the relationship between firms' innovativeness and their participation in stock markets. There are two fields of financial economics most relevant to the study of such a relationship: literature on the going public decision, and that on the capital structure of companies. Existing research offers clues on how the capital structure of companies and decisions to go public relate to their innovativeness, but empirically it focuses almost exclusively on manufacturing. Such focus leaves a yawning research gap, considering that services firms account for two thirds to three quarters of employment in developed economies, not to mention claims that the current 
wave of innovation is driven by information technology services firms. The scarcity of research on the relationship between innovation and stock markets in services sector is even more striking when we recall that the most recent stock market boom was centred on Internet related companies that belong to services rather than manufacturing sector. This paper contributes to the existing research by analysing the relationship between innovativeness and stock market participation in both manufacturing and services firms in 32 countries.

Financial economic literature on going public and capital structure is silent on services companies in terms of theory and largely neglects them in empirical terms. The latter may be due to the fact that available statistical sources lag behind real world developments, and still offer less information on services than on manufacturing firms. The problem with the prevailing theoretical approach, in turn, is that it focuses on the features of conventionally understood innovation, such as technology and formal research and development, and lacks consideration for features typical of innovation in services, such as knowledge intensity. In these circumstances, in this paper I turn to the multidisciplinary field of innovation studies, which tends to treat innovation in a broad fashion and attempts to conceptualise innovativeness for any type of firm, above the level of conventional, and in some respects old-fashioned distinctions between manufacturing and services. The problem here, however, is that literature on innovation in general, and on innovation in services in particular, pays little attention to the going public decision or capital structure. Given these problems, the second general contribution of this paper is to combine financial economics and innovation studies in order to address the relationship between innovativeness and stock market participation.

The paper uses a dataset covering nearly 100,000 companies in 30 European countries as well as the USA and Japan to address the following questions:

1. Is there a relationship between innovativeness and stock market participation of firms in manufacturing?

2. Considering that innovation is in some respects different in services than in manufacturing, is there a relationship between innovativeness and stock market participation of firms in services?

To start with, the paper demonstrates that services account for an absolute majority of listed firms in the world. This finding reinforces the agenda of research on stock market activities of services firms. In response to the core questions, I show that while stock market participation increases with high-technology intensity in manufacturing, it increases at least as consistently with knowledge intensity of services firms. The only group of countries where the relationship between high-technology intensity and stock market participation does not hold are the transition countries of Central and Eastern Europe. This may be explained with the pecking order theory in financial economics or the impact of privatisations. The former would imply that high-technology companies in transition economies turn for financing to banks rather than to relatively poorly developed stock markets. Privatisations, in turn, could obscure the relationship under consideration by bringing to the stock market hoards of formerly state-owned firms 
irrespective of their financial needs underpinned by their innovativeness. The role of institutional environment is also confirmed with regard to firms in non-transition countries. Finally, the paper argues that while the Internet boom was responsible for bringing large numbers of services companies to the stock market, the relationship between stock market participation and innovativeness is likely to have existed before the boom.

Beyond adding to the stock of knowledge on why companies in different sectors and countries go public, the results of this paper are important for one principal reason. They highlight the possibility that the development of stock markets positively affects innovation (or at least certain types of it) in an economy. While the static nature of data used in this paper does not allow and exploration of the direction of causality between stock market development and innovation, the paper indicates new avenues for research on the impact of financial structure on economic development (Levine 2004).

The paper proceeds as follows. Section 2 defines innovativeness and stock market participation and links them using a combination of insights from financial economics and innovation studies. This is followed by the description of methodology and data, including a novel measure of stock market participation. Section 4 presents stock market participation by country and by sector, and compares it between manufacturing and services. The following two sections address the core research questions, investigating the relationship between innovativeness and stock market participation, using bivariate and multivariate analysis. Section 7 concludes, offering implications and directions for further research.

\section{Linking innovativeness with stock market participation}

Let us define innovation in a Schumpeterian fashion as new combinations of tangible (technology) and intangible (knowledge) inputs that are economically more viable than the old ways of doing things. Such a definition covers: i) introduction of new goods or new qualities of goods, ii) introduction of new methods of production, iii) opening of new markets, iv) finding new sources of inputs, and v) finding new ways of organising business (Schumpeter 1934). Innovative firms are those that carry out innovations. Companies that participate in stock markets, in turn, can be defined as those accessing public equity markets. To be sure there are different degrees of stock market participation. A company can just have its shares quoted and traded on an over-thecounter market or listed. Fuller participation involves the issuance of new shares and raising funds through the public stock market. With these broad definitions in mind, what connections between innovativeness and stock market participation can be found in the existing theoretical and empirical research?

First of all, innovative firms can be expected to have more investment and growth opportunities that make them need more capital than less innovative firms. They are less likely to satisfy their demand for capital from retained earnings and more likely to turn to external sources. External finance is costly, as external financiers will never have information that is available to corporate managers, and face adverse selection problems. According to Myers and Majluf (1984) these problems are minimised by the issuance of the safest security, the pricing of which is least sensitive to managers' 
private information. Thus, debt, whose risk depends primarily on the value of collateral, is issued before equity. The rights of creditors are clearer and violations of these rights easier to verify in courts than the rights of shareholders. This logic leads to the proposition of the pecking order theory, according to which firms tend to satisfy their financial needs from internal sources first, debt second, and equity in the last instance. In addition, it is plausible to expect that by using external equity firms enhance their bargaining power in relation to banks (Pagano et al. 1998, Röell 1996). The implication of the pecking order theory is that the relationship between the use of external equity and innovativeness may be non-monotonic. Firms with moderate levels of innovation may actually use more debt than firms with no or little innovation, but as innovativeness rises above moderate levels, the use of external equity increases. Aghion et al. (2004) corroborate such a hypothesis with empirical results on the UK listed companies and their secondary equity issues.

The second major factor that may affect debt-equity structure, and at the same time be related to innovativeness, is the structure of firms' assets. Shleifer and Vishny (1997) argue that equity is most suitable when a company has a large share of intangible items in its assets. Intangible assets make poor collateral and have little value in case of company liquidation. This is particularly true for assets that are specialised and firm specific, i.e. it would be very difficult to sell those for use in a different company (Titman 1984). As innovative firms are more likely to be strong in know-how, patents and other intangible assets rather than tangible assets like plant or machinery, and their assets are more likely to be firm specific, they are less likely to rely on collateral-hungry banks and more on stock markets. Empirical research tends to confirm the expected positive relationship between leverage and the share of tangible assets (Harris and Raviv 1991, Rajan and Zingales 1995).

Beyond investment opportunities and asset structure, there are also theories that suggest that public equity markets are more efficient than banks in collecting and processing information needed to evaluate innovative firms and their projects. Subrahmanyam and Titman (1999) highlight the role of serendipitous (collected by chance, in the course of life) information in the assessment of new industries, e.g. Internet. Public equity markets rather than private financiers or banks are natural environments for the generation and use of such information. In a similar manner, Allen and Gale (1999) develop a model indicating that public equity markets are a superior source of financing for projects that attract a diversity of investors' opinions about their likely commercial success. Interpreting that model Carlin and Mayer (2003) argue that as public markets aggregate diverse views of a large number of market participants, they could be expected to be associated with speculative investments, e.g. in high technology industry. In contrast, banks tend to be biased towards prudence, and ineffective in gathering and processing information in new, uncertain situations involving innovative products and processes (Morck and Nakamura 1999, Weinstein and Yafeh 1998). To my knowledge, there are no direct empirical tests of the theories by Subrahmanyam and Titman or Allen and Gale, however it is worthwhile noting the study by Brau and Fawcett (2006) on US IPOs, demonstrating that enhancing reputation and attracting analysts' attention is a much more important motivation for the going public of high technology than other firms. 
None of the above theories of capital structure and going public decision discriminates against services; they are just silent on it. They make no distinction between manufacturing and services, and there seems to be no reason why the relationship between innovativeness and stock market participation should not apply to manufacturing and services firms alike. Further indirect support for such a contention can be found in innovation studies, which have tried to compensate for decades of neglecting services in research. To start with, innovation studies remind that even the Schumpeterian definition of innovation, originating in the times when services were incomparably less prominent in the economy, is rich enough to encompass innovation in services (Drejer 2004). Second, they propose a framework for conceptualising innovation as a combination of competencies and technologies, which applies to both manufacturing and services (Gallouj and Weinstein 1997). Third, empirical innovation studies show that innovation dynamics in some services is more similar to certain parts of manufacturing than to other services and vice versa (Preissl 2000, Tether 2003). They document a blurring of borders between manufacturing and services, whereby innovation in manufacturing involves increasing amounts of knowledge, while innovation in services needs to engage with applications of high technology originating in manufacturing.

Fuzzy boundaries between innovation in manufacturing and services do not mean, however, that no systematic differences remain, and that these differences could not influence the propensity of innovative services firms to access public equity markets. One issue is the perception that innovation in services is less costly than in manufacturing. If this was true then innovative services firms would need public equity markets less than their manufacturing counterparts. Such a thesis is highly problematic on both conceptual and empirical grounds. While innovation in services requires less formal research and development expenditures, to be innovative in a Schumpeterian competitive sense innovative services firms need to invest in knowledge, which may be as costly as physical/tangible assets. Sirilli and Evangelista (1998) demonstrate that access to finance is as important a barrier to innovation for services firms as it is in manufacturing.

The second potential issue with the relationship between innovativeness and stock market participation in services is not the cost but the character of investment. Research on professional business services (PBS including law, accountancy, tax, and management consultancy services), which represent a crucial part of innovative services (Wood 2002), shows that the main investment in such firms are highly skilled, increasingly mobile, and difficult to retain individuals. In addition, these firms are perceived as particularly difficult to monitor for outsiders, implying big agency problems for external equity investors (Teece 2003). In consequence, private partnerships may be an optimal governance structure for such firms, providing better incentives to employees. In addition, there may be regulatory reasons for these firms to remain private partnerships. Some types of PBS in some countries face legal restrictions on going public in order to prevent conflicts of interests. The proponents of such regulation argue that a law or accountancy firm couldn't be expected to objectively evaluate a client, if the latter happens to be a major shareholder in the evaluating firm. Others, however, argue that the predominance of private partnerships in PBS is a relic 
of history rather than an optimal model of organisation (Greenwood and Empson 2003). Van Nordenflycht (2007), for example, mentions the lifting of going-public restrictions in investment banking and advertising in the USA in 1970s, and shows that in the advertising sector public corporations do not perform worse than private partnerships. It should also be taken into account that listing may offer PBS new ways of motivating highly skilled and mobile professionals, such as stock options, just as it is the case in high technology manufacturing.

One final issue that may counteract a positive relationship between innovativeness and stock market participation in services is the difficulty of protecting innovations. Given the limited use of patents in services, protecting innovation may be more difficult than in manufacturing (Gallouj and Weinstein 1997). At the same time, going public involves stricter disclosure and the risk of losing confidentiality on corporate activities (Pagano et al. 1998). As a result, the incentives of innovative services firms to go public could be lower than for their manufacturing counterparts. While this factor cannot be ruled out, the overall evaluation of arguments about the expected relationship between innovativeness and stock market participation in services appears to be strongly in favour of a positive relationship.

This section is not meant to imply that innovativeness is the primary factor driving the engagement of firms with stock markets. The latter is likely to be affected by a myriad of factors including firm size, profitability, as well as a host of country-specific institutional factors such as taxation, bankruptcy codes or disclosure standards (Röell 1996). While some of these factors are considered in this paper, the emphasis, however, is on the relationship between innovativeness and stock market participation within countries. This focus is justified by the absence of prior studies trying to conceptualise the interplay of innovation and stock markets in services, as well as by the nature of data used in the paper. It is the description of data and methodology that I turn to in the following section.

\section{Methodology and data}

To analyse the relationship between stock market participation and innovativeness this paper uses industry-level data for 47 sectors in 32 countries. The data comes from the ORBIS database by Bureau Van Dijk Electronic Publishing (BDEP) and is valid for the end of September 2006. Geographical coverage consists of all 27 European Union member states, Iceland, Norway, Switzerland, as well as the USA and Japan. The data covers 23 types of manufacturing and 24 types of services following NACE codes (as amended in 2001, also known as Rev.1.1. NACE codes), the principal statistical classification of economic activities within the European Union.

\section{Stock market participation}

Stock market participation (SMP) of each sector in each country is calculated as the ratio of the number of publicly traded companies to the number of all companies with turnover exceeding $€ 50 \mathrm{~m}$. Thus, companies participating in stock markets are defined as those that are publicly listed or at least publicly quoted and traded. This broad definition is applied in order to cover all alternative, smaller company, and technology 
focused segments of stock markets, which is important given that the paper focuses on the presence of innovative firms on stock markets. A detailed list of each country's stock market segments covered in the paper is presented in appendix 1. Data on the numbers of publicly traded companies were compared with those available from such sources as the World Federation of Exchanges, the Federation of European Stock Exchanges, and websites of individual stock exchanges. No major discrepancies were detected. The practical reason why the paper could not use a more familiar category of listed companies was that such data are not available in ORBIS. This is, however, not a significant problem, since the objective of the paper is to capture all companies participating in stock markets. In fact, for most countries the number of publicly traded companies as recorded in ORBIS is identical or very similar to the number of listed companies recorded by alternative sources.

To assess SMP it is crucial to carefully delimit the broader population of companies in the underlying economy, to which the set of stock market participating firms is compared. It is not possible to consider all enterprises existing in an economy due to the difficulty of obtaining internationally comparable data. Such an approach would also fail to recognise that companies participating in stock markets are relatively large, mainly as a result of fixed costs of stock market participation such as reporting costs as well as initial and ongoing listing fees (Pagano et al. 1998; Oxera 2006). For this reason this paper compares the set of stock market companies to all companies with turnover in excess of $€ 50 \mathrm{~m}$, adjusted to the price level in a given country. The threshold of $€ 50 \mathrm{~m}$ is used officially in the European Union to distinguish between medium and large companies. Companies are assigned to countries where they are headquartered. They are considered as stock market traded, if they are traded on any stock market in the world, not necessarily their home country market. This is to account for the growing numbers of companies that by-pass their domestic stock markets, for example Irish companies listed on the London's Alternative Investment Market, but not on the Irish Stock Exchange. In short, the ratio of SMP relates the number of firms that participate in stock markets to the number of all large firms in the underlying economy.

Data on the number of large companies operating in the underlying economies were collected by filtering companies with turnover in excess of $€ 50 \mathrm{~m}$ out of all companies included in ORBIS. Turnover figures are based on consolidated financial statements, if available (unconsolidated otherwise), for the last financial year, for which they were available (mostly 2005). The thresholds of $€ 50 \mathrm{~m}$ and $€ 200 \mathrm{~m}$ are adjusted to the country price level, using Eurostat-OECD comparative price levels for 2005, based on the price of a representative basket of consumer goods and services (for details see OECD 2006). The comparative price level for the 30 OECD countries combined is set at 1; indices for individual sample countries in 2005 range from 0.40 for Bulgaria to 1.46 for Iceland. The adjusted turnover thresholds are calculated by multiplying $€ 50 \mathrm{~m}$ by a country's comparative price level, and for non-Eurozone countries are translated into domestic currency using the respective Euro exchange rates as at the end of September 2006.

An important issue is whether the ORBIS database captures reliable numbers of all large companies operating in the sample countries. Unfortunately, it is not possible to 
compare the ORBIS data with those from the Eurostat's New Cronos database, for example, since the latter defines large companies on the basis of the number of employees, not turnover, and the data are often out-of-date and available only for few countries. The use of multiple sources of corporate data by the BVDEP, resulting in impressively high numbers of companies included in ORBIS serves as an important source of assurance. While the numbers of publicly traded companies for European sample countries, Japan, and the USA were 7,830, 3,609, and 8,280 respectively; and the numbers of large companies were 54,569,11,292, and 31,966; the numbers of all companies covered by ORBIS were over 10 million, over 1 million, and nearly 2 million, respectively. Thus, large companies represent less than $1 \%$ of all companies in the ORBIS database. Given that the likelihood of the BVDEP having data on a company grows with the size of the company, the coverage of large companies in the paper should be reliable.

Any analysis comparing numbers of publicly traded companies between countries runs the risk of comparing the incomparable. What counts as a publicly traded company in one country, would not necessarily be considered as such in another country. Listing rules differ between countries and between stock exchanges. Lenient listing rules can result in high and strict rules in low numbers of recorded issuers. Considering these issues, the paper does not focus on comparing absolute figures on SMP between countries. The emphasis is instead on comparing SMP rates between sectors of companies within countries.

\section{Innovativeness}

To capture innovativeness of each sector the paper uses the OECD/Eurostat classification that divides manufacturing into four, and services into three groups (Eurostat 2006). Its advantage is that it combines the traditional understanding of R\&D intensity, based on technological and tangible innovations, with the concept of knowledge intensity, much more suitable to services than the traditional definition. The allocation of each manufacturing and services sector into the seven groups of the OECD/Eurostat classification is presented in appendix 2. Agriculture, mining, utilities and construction firms are not classified by the OECD/Eurostat, and are excluded from the analysis.

\section{Contribution}

The contribution of this paper in terms of methodology is twofold. First, the paper proposes a novel measure of stock market participation. The numbers of listed companies have been related to countries' GDP (e.g. Röell 1996) or population (La Porta et al. 1997) before, but not to the number of potential issuers operating in the underlying economy. Second, within empirical firm-level or industry-level research on the relationship between innovation and stock markets, prior international studies have focused exclusively on manufacturing (recent examples include Aghion et al. 2004, Carlin and Mayer 2003). While studies encompassing services do exist they use data on single countries only (e.g. Fischer 2000, Kukies 2000). To my knowledge, this is the first paper investigating international data on the relationship between innovativeness and SMP for services and manufacturing. 


\section{Stock markets participation of services vs. manufacturing firms}

Table 1 presents the number and the structure of companies by country. The total sample consists of nearly 100,000 firms with price-level adjusted turnover exceeding $€ 50 \mathrm{~m}$, nearly 20,000 of which are publicly traded. In every country there are more large firms in services than in manufacturing, and services account for $70 \%$ of the total number of large firms. This simply confirms a well-known fact that services represent a lion's share of today's world economy. What has not been pinpointed before, however, is that services firms account also for a majority of publicly traded firms. Their share in the total sample equals $62 \%$, and exceeds that of manufacturing in 23 out of 32 sample countries, with the 9 exceptions being 7 transition countries in Central and Eastern Europe, Finland, and Greece. In non-transition economies of Europe (all European countries in the sample, excluding the 10 transition economies) there are twice as many publicly traded services firms as manufacturing firms. The observation that services constitute a smaller share of the stock market than of the underlying economy indicates a lower SMP of services firms. In fact, in all countries except Austria, Malta, Norway, and the UK services have a lower SMP rate than manufacturing.

Table 1 also reveals how SMP varies between countries. While in the total sample there are approximately 4 large firms for every publicly traded firm in manufacturing and 5 in services, in Cyprus and Bulgaria there are more publicly traded than large firms. On the other extreme, in the Czech Republic there are 70 times as many large firms as there are publicly traded firms. The absolute SMP rates differ partly because the definition of a publicly traded company differs across countries. How these definitions differ is irrelevant to the rest of the paper, as it focuses on the variation of SMP within countries, not across countries.

As presented in appendix 2, SMP differs greatly across sectors. Within manufacturing it ranges from recycling, as a sole sector with SMP below 0.10, through a large cluster of sectors with SMP of $0.15-0.16$, to a maximum SMP of 0.65 for the manufacture of radio, television, and communication equipment and apparatus. Within services, there are several sectors with SMP below 0.10, and the maximum value of SMP is 0.80 for activities auxiliary to financial intermediation (including brokerage firms), followed by computer and related activities with SMP of 0.75. Other business activities, including law, accountancy, and advertising firms, referred to as professional business services in section 2, have SMP of 0.15 , below the average for all services of 0.18 . In general, it appears that the variation of SMP is greater across sectors of services than across sectors of manufacturing firms.

This overview of the dataset leads to one major conclusion. The fact that the majority of firms participating in stock markets are services firms, combined with the observation that SMP varies more across different types of services firms than across manufacturing, underscores the value of including services in the study of factors affecting firms' engagement with stock markets. This value applies in particular to the study of the relationship between SMP and innovativeness.

\section{Innovativeness and stock market participation}


Table 2 presents SMP rates for all countries and figure 1 depicts the results for Europe, Japan and the USA, the four largest EU economies, and the four largest EU transition economies. The results suggest a positive relationship between innovativeness and SMP in manufacturing. High technology (HT) firms participate in stock markets to a higher extent than any other group of manufacturing firms in the USA, Japan, and nontransition Europe. Within the latter region, Ireland is the only country where companies other than HT have the highest SMP. However, whether a company is medium high technology (MHT), medium low technology (MLT) or low technology (LT) does not seem to matter much for SMP. While in the USA, MHT firms have higher SMP than MLT firms, the same cannot be said of non-transition Europe. Moreover, in the USA, Japan, Germany and Italy LT firms have higher SMP than MLT firms. The observation that SMP peaks consistently at the high end of the scale of innovativeness, but does not vary significantly for moderate or lower sections of that scale, seems to support the pecking order theory (Aghion et al. 2004). When levels of innovativeness increases, firms turn first to banks, not necessarily stock markets for additional financing. It is only when level of innovation is very high that stock market financing becomes essential.

Within manufacturing, transition economies do not exhibit a positive relationship between innovativeness and SMP, not even for the most innovative firms. In fact, for EU transition economies as a whole, the relationship appears reversed, whereby LT firms have the highest and the HT firms the lowest SMP rates. Three possible and related explanations can be put forward. First, it is possible that many formerly state-owned LT firms have been brought to the stock market via privatisation, which obscures the relationship between innovativeness and SMP. Ljungqvist et al. (2003) estimate the share of privatisations in IPOs in 1992-1999 at 50\% for Eastern Europe, while for Western Europe the figures range from $0.9 \%$ in the UK to $12.5 \%$ in Italy. The second possible explanation that the existing HT firms in transition countries are not encouraged to enter stock markets to the extent it takes place in Western Europe, USA or Japan. Developed stock market segments for HT firms are rare in these countries. The third explanation is that the legal and regulatory environment of stock markets (such as the protection of shareholders' rights) is relatively underdeveloped, so that even HT firms still turn to banks rather than stock markets to satisfy their investment needs. The last explanation is consistent with the finding of Carlin and Mayer (2003) that in low GDP countries (i.e. Korea, Mexico, Portugal, Greece in their paper) the positive relationship between corporate growth and bank dependence is much stronger than that between growth and equity dependence.

For services, hitherto neglected in the study on the relationship between innovation and stock markets, the results are striking. In every single country in the sample, less knowledge intensive (LKI) services have the lowest SMP rate. In 24 out of 32 countries, high technology knowledge intensive (HTKI) services have higher SMP than other knowledge intensive (OKI) firms, and OKI higher SMP than LKI. The exceptions are Spain, Cyprus, Malta, and 5 transition economies. In Poland and Hungary, however, the consistent positive relationship between SMP and innovativeness holds. These findings should be compared with those for manufacturing. First, the implication of the pecking order theory about the non-monotonic relationship between innovativeness and SMP does not seem to apply to services. With regard to privatization, the lack of support for 
innovative firms, and the legal and regulatory environment, their role may still be discernible, but is at least weaker than for manufacturing. In other words there seems to be something so inherently strong about the relationship between innovativeness and SMP in services, that other intervening factors that play an important part in manufacturing, fade away in the background with respect to services. One might point out that the category of the most innovative services i.e. HTKI mixes innovation in a conventional sense with knowledge intensity, and this is decisive for the relationship between innovativeness and SMP in services. As we can see in figure 1, however, the drop in SMP as we move form OKI to LKI is as pronounced as that between HTKI and OKI.

\section{Multivariate analysis}

To further test the relationship between innovativeness and SMP, I move to multivariate regression analysis using the following equation:

$$
\operatorname{SMP}_{i k}=\alpha \cdot I_{i}+\beta \cdot \text { Size }_{i}+\gamma \cdot \text { Share }_{i k}+\delta \cdot\left(I_{i} \cdot \text { LRE }_{k}\right)+\phi \cdot\left(I_{i} \cdot \text { IBoom }_{k}\right)+\text { dummies } \varepsilon_{i k}
$$

The equation is estimated separately for manufacturing and services and regresses SMP for each sector in each country on variables characterizing sectors and countries. Variable $I$ denotes innovativeness, defined in manufacturing as number 1 for LT, 2 for MLT, 3 for MHT, and 4 for HT firms; in services as 1 for LKI, 2 for OKI, and 3 for HTKI firms. We expect $\alpha$ to have a positive sign. Size is defined as the median turnover of all firms in sector $i$ across all 32 countries for which data are available in ORBIS. According to the view that larger firms are more likely to be listed (Pagano et al. 1998), we could expect sectors with larger firms to command higher $S M P$, and $\beta$ to be positive. Share denotes the share of a sector $i$ in country $k$ in the total number of firms in country $k$ in manufacturing and services respectively. The coefficient $\gamma$ is expected to have a negative sign, as there may be significant first-mover advantages in going public. Keeping other incentives equal, the smaller a sector, the more visibility and reputation a firm from that sector may gain by being public (Maksimovic and Pichler 2001). Companies from smaller sectors would also have fewer peers to compete with for the attention of diversification-seeking investors.

The next variable is an interaction term of innovativeness and legal and regulatory environment. $L R E$ is defined as the mean of two World Bank governance indicators: regulatory quality and rule of law, both averaged over the years 1996-2006. These indicators encompass such issues as the flexibility of regulation that promotes private sector development, the quality of contract enforcement, and the protection of property and shareholder rights, which are vital for the development of financial markets, and stock markets in particular (La Porta et al. 1997). The use of the interaction term is inspired by prior research. Rajan and Zingales (1998) show that industrial sectors that depend more on external finance grow faster in countries with more developed financial markets (as measured with the ratio of the sum of equity market capitalization and domestic credit to GDP, and the quality of accounting standards). Carlin and Mayer (2003) in turn, demonstrate that industries that depend more on equity conduct more R\&D in countries with better accounting standards. Both of these papers relate growth or $R \& D$ to the interaction between equity (or external finance) dependence and 
accounting standards. My proposition here is to use similar variables but in a different order, and relate $S M P$ (similar to the concept equity dependence) to the interaction between innovativeness and the legal and regulatory environment. I use $L R E$ instead of the quality of accounting standards as a broader concept capturing the institutional environment of stock markets (Kaufmann et al. 2008). I expect SMP to grow with innovativeness in countries that have high $L R E$, i.e. the expected sign of $\delta$ is positive. Apart from being a variation on prior research, this hypothesis is based on the bivariate analysis that indicated that the positive relationship between innovativeness and SMP is absent or weaker for transition economies, and is particularly strong for highly developed stock markets such as the USA and the UK.

The following variable is interaction between innovativeness and the magnitude of the Internet boom (IBoom), and deals with the impact of the latter on the relationship between innovativeness and SMP. Considering that at the peak of the Internet boom in 1999-2000 technology companies accounted for 72\% of IPOs in the USA (Ritter and Welch 2002), and new segments of stock markets for young innovative firms sprang up across Europe (Posner 2005) it is possible that the relationship between innovativeness and $S M P$ is primarily the legacy of this short episode in the recent history of stock markets. In the absence of data on the time of going public, I calculate the percentage increase in the number of listed domestic companies by country between the end of 1997 and the end of 2000. Here I follow Ofek and Richardson (2002) who define the start of the boom in the USA as January 1998 ad the end as February 2000. Given that in Europe the boom lasted a bit longer, and there were few IPOs in the remainder of 2000 after the bubble burst, the increase in the number of listed domestic companies between 1997 and 2000 should be an appropriate measure of the magnitude of the boom in terms of primary stock markets. The variable makes sense only for nontransition economies, since numbers of IPOs in transition economies could have been affected considerably by privatisations through stock market rather than the Internet boom. If $\phi$ turns out positive, this would mean that SMP grows with innovativeness in countries that experienced strong Internet boom. As services firms constituted an absolute majority of IPOs of the Internet boom (Ofek and Richardson 2002), we could expect a positive relationship between SMP and the interaction variable particularly with regard to services.

Finally, country dummies are used in the equation, with the USA as the reference category, in order to account for the lack of direct comparability between SMP rates across countries. In other words, the relationships between SMP and explanatory variables are estimated in relation to country averages. Data on Size by sector are presented in appendix 2; on $L R E$, and IBoom by country, as well as descriptive statistics on SMP and Share are presented in appendix 3. Results were estimated for the samples of all 32 countries, as well as for 22 non-transition, and 10 transition economies separately. As estimations for transition economies yielded no statistically significant results for any of the coefficients, the results presented in table 3 are for non-transition countries only. The maximum possible number of observations is 506 ( 23 sectors by 22 countries) for manufacturing and 528 ( $24 \times 22$ ) for services. The actual numbers are lower, since some sectors in some countries have no large firms, and no SMP rate can be calculated for them. 
The variable of innovativeness behaves as hypothesized, showing a strong positive relationship with SMP. The coefficient of innovativeness loses its positive sign only for manufacturing, when the impact of $I$ on its own seems to be overwhelmed by the impact of the interaction of $I$ with $L R E$. Supporting the results of bivariate analysis, the relationship between $I$ and $S M P$ appears much stronger for services than for manufacturing, with coefficients for the former four times bigger in specifications (1) to (3). As we move from a less to a more innovative category of services, SMP increases on average by $0.21-0.24$, so for every 4-5 large firms existing in the underlying economy, one more is publicly traded. An equivalent step in manufacturing implies an increase by only one publicly traded company per 20 large firms.

The coefficients of Size are negative and significant for both manufacturing and services, what contradicts our expectations. It appears that sectors made of smaller firms tend to have higher SMP than those made of larger firms. Within HTKI services, for example, post and telecoms firms are typically bigger than R\&D or computer firms, but have much lower SMP. Within LKI services hotels and restaurants are typically half the size of firms in wholesale and commission trade, but have much higher SMP. Within LT manufacturing, tobacco firms are typically five times the size of firms manufacturing dressing but are much more poorly represented on stock markets. Petroleum firms have the largest median size of all MLT sectors combined with the lowest SMP. As expected the share of a sector is negatively related to SMP. Manufacturing of food products and wholesale and commission trade are the largest (in terms of the number of large firms) sector in manufacturing and services respectively, and have some of the lowest SMP rates. The negative relationship between Size and SMP is stronger and more significant for services than manufacturing. The relationships between $S M P$ and both Size and Share should be subject of further investigation that goes beyond the scope of this paper.

The relationship between $S M P$ and the interaction of $I$ and $L R E$ is positive, as expected, with stronger results for manufacturing than services. In specifications (5) and (9) for manufacturing, the impact of the interaction appears so strong that it gives $I$, considered on its own, a significantly negative coefficient. This seems to confirm observations from bivariate analysis. As can be seen in figure 1, the relationship between innovativeness and $S M P$ is much stronger for the USA than for Japan, the latter having a much lower LRE ranking. Within EU the relationship is strongest for the UK, and weakest for Italy, the latter representing a much less friendly environment for stock market development. Finally, there seems to be no support for the existence of a strong relationship between $S M P$ and the interaction of $I$ with IBoom. The significance of the obtained coefficient for manufacturing is low, and its sign for services changes between specifications.

To test the robustness of the positive relationship between the interaction of $L R E$ and $I$ and $S M P$, in estimations not reported in the table, $L R E$ in the interaction variable was substituted with the following variables: the quality of accounting standards (as used by Carlin and Mayer 2003), ownership concentration of publicly traded firms, the ratio of pension fund assets to GDP, the ratio of private equity investments to GDP, stock market capitalization divided by GDP, and GDP per capita. For services, none of the above had a significant coefficient. For manufacturing the coefficient for accounting standards, 
private equity, stock market capitalization to GDP, and GDP pc were positive, and that for ownership concentration was negative and significant. These results suggest that as the level of stock market development, however measured, increases and conditions for it improve, the propensity of highly innovative manufacturing firms relative to less innovative firms to access stock markets increases.

The multivariate analysis leads to the following conclusions. First of all, it confirms the findings of the bivariate analysis that there is a relationship between innovativeness and SMP for manufacturing and services, but the relationship for the latter is stronger. Second, it is confirmed that the relationship holds for the population of firms from nontransition countries, but not for those from transition countries. Third, the support for the role of legal and regulatory environment in shaping the relationship between innovativeness and $S M P$ is upheld and applies mainly to manufacturing. Fourth, SMP increases with the falling share of a sector in the economy, which seems to support the thesis on the first mover advantages in listing. Fifth, it is intriguing that $S M P$ is lower in sectors with larger average corporate size. Finally, the evidence on the role of the Internet boom is weak and mixed, suggesting that the relationship between innovativeness and SMP documented in this paper cannot be claimed to be determined historically by the Internet boom and burst of 1998-2000.

\section{Conclusions and implications}

The objective of the paper was to investigate the link between stock markets and innovation, by focusing on the relationship between firms' innovativeness and their participation in public stock markets. The relationship was conceptualized using literature on capital structure and going-public decision, combined with insights from innovation studies. This led to the conclusion that there are no reasons, why a positive relationship between innovativeness and stock market participation, which is commonly expected and partly documented in manufacturing, should not apply to services, for which it has hardly been considered before, even though services firms account for the majority of listed companies. Empirically, the paper analysed the relationship between innovativeness and stock market participation for both manufacturing and services, using sector-level data on 47 sectors in 32 countries.

The main empirical finding of the paper is the positive and significant relationship between innovativeness and stock market participation. Strictly speaking, in more innovative sectors there are more publicly traded firms in relation to the number of large firms than in less innovative sectors. The relationship appeared strong in bivariate analysis, and was confirmed in multivariate analysis. The value of this result lies in the fact that prior studies have been restricted in their international coverage, and hardly ever included services firms. While past research pays little attention to the link between innovativeness and stock market participation in services, in this paper the relationship was actually found to be stronger for services than for manufacturing. In manufacturing, while the most innovative firms have by far the highest levels of stock market participation, as we move to the middle and the bottom of the scale of innovativeness, the relationship peters out. This may serve as indirect evidence in favour of the pecking order theory of finance (e.g. Aghion et al. 2004). As level of innovativeness, and the accompanying capital needs, increase firms may turn to banks 
in the first instance to satisfy them. Stock market financing becomes an attractive alternative only for the most innovative, and most capital and visibility-hungry firms. Why, if true, such a relationship does not apply to services, is an issue for further research.

Second, the institutional environment of stock markets matters for the relationship between innovation and stock markets. In other words, the relationship is likely to differ between countries as a reflection of their diverse institutions. One piece of evidence here is that the positive relationship between innovativeness and stock market participation within the EU transition countries, does not appear at all for manufacturing, and is weak and insignificant for services. This may be explained with the history of privatisations, focused on state-owned companies in traditional, not very innovative sectors, obscuring the relationship in question. A complementary explanation may be the relatively weak legal and regulatory environment of stock markets in transition economies. They may all still be at a stage, where even the most innovative firms use banks, without recourse to underdeveloped stock markets. The role of institutional environment is confirmed by the results for non-transition countries. The relationship between innovativeness and stock market participation is stronger in non-transition countries with high scores in terms of legal and regulatory environment. This again may be interpreted in favour of the pecking order theory. What complicates the picture, however, is that for services the role of the institutional environment appears weaker than for manufacturing.

Third, within multivariate analysis, I regressed stock market participation on the interaction of innovativeness with the magnitude of the Internet boom, but found no significant relationship. This does not contradict the obvious fact that the boom brought to the stock markets a myriad of services firms developing and using IT including Internet. It does, nevertheless, support the view that the positive relationship between innovativeness and stock market participation holds in countries where the boom was less significant, and indicates that the relationship had existed before late 1990s. It does not mean that IT-related firms have been the most stock market savvy firms for decades. Take Dimson et al. (2002), for example, who show that in 1900 railway companies accounted for approx. 50\% of stock market capitalization in the USA and the UK. At present, the OECD/Eurostat classification puts railways in the category of the least innovative services firms. The forms of innovation, and the definition of innovativeness change over time by the very nature of innovation. It does not require an in-depth knowledge of financial history to remark that companies at the forefront of economic expansion have probably always dominated stock markets. Just as we can see 1900 as the peak of stock market significance attained by railways, following their growth of the and consolidation, we can interpret the Internet boom of 100 years later as a wave of IT-based growth entering the stock markets. In summary, the future research into the links between innovation and stock markets needs to combine the economic logic with the understanding of institutional diversity (geography) and their history.

By the virtue of applying a large international dataset and giving special consideration to services, this paper contributes to the well-established literature on the relationship 
between finance and development (Levine 2004). The study of the relationship between stock markets and innovation is central to this literature, and has massive potential policy implications. At the same time, it is very contentious. Some argue that stock markets promote innovation in ways that cannot be attained by banking sectors (e.g. Michelacci and Suarez 2004). Others remain skeptical, claiming that while financial development matters for economic growth, the structure of financial markets (stock markets vs. banks) does not (Merton and Bodie 2004). Documenting a strong relationship between innovativeness and stock market participation in both manufacturing and services in a large international sample, underscores the possibility financial structure may indeed matter for innovation. Of course, the direction of causality between innovativeness and stock market participation cannot be analysed with data available for one point in time only. One suggestion for further research would be to relate the level of stock market development to the change in the number and structure of firms according to their innovativeness.

\section{References}

Aghion, P., Bond, S., Klemm, A., Marinescu, I. 2004. Technology and financial structure: Are innovative firms different? Journal of the European Economic Association 2(2-3), 277-88.

Allen, F., Gale, D. 1999. Diversity of opinion and financing of new technologies. Journal of Financial Intermediation 8, 68-89.

Brau, J. and Fawcett, S. 2006. Initial public offerings: an analysis of theory and practice. Journal of Finance 61, 399-436.

Carlin, W., Mayer, C. 2003. Finance, investment, growth. Journal of Financial Economics 69, 191-226.

Dimson, E., Marsh, P., Staunton, M. 2002. Triumph of the Optimists: 101 Years of Global Investment Returns. Princeton University Press.

Drejer, I. 2004. Identyfying innovation in surveys of services: A Schumpeterian perspective. Research Policy 33, 551-62.

Eurostat. 2006. High tech industries and knowledge based services. Statistics in Focus: Science and Technology 13/2006.

Fischer, C. 2000. Why do companies go public? Empirical evidence from Germany's Neuer Markt. www.kmf.bwl.uni-muenchen.de/publikationen/fischer.html

Gallouj, F., Weinstein, O. 1997. Innovation in services. Research Policy 26, 537-56.

Greenwood, R., Empson, L. 2003. The professional partnership: Relic or exemplary form of governance? Organization Studies 24(6), 909-33.

Harris, M., Raviv, A. 1991. The theory of capital structure. Journal of Finance 46, 297355. 
Kaufmann, D., Kraay, A., Mastruzzi, M. 2008. Governance matters VII: Aggregate and individual governance indicators 1996-2007. Policy Research Working Paper, World Bank June 2008.

Kukies, J. 2000. The effects of introducting a new stock exchange on the IPO process. Manuscript, www.cepr.org/meets/wkcn/5/554/papers/kukies.pdf.

La Porta, R., Lopez-de-Silanes, F., Shleifer, A., Vishny, R.W. 1997. Legal determinants of external finance. Journal of Finance 52(3), 1131-50.

Levine, R. 2004. Finance and Growth: Theory and Evidence. www.ssrn.com.

Ljungqvist, A.P., Jenkinson, T., Wilhelm, W.R. 2003. Global integration in primary equity markets: The role of U.S. banks and U.S. investors. Review of Financial Studies 16(1), 6399.

Maksimovic, V., Pichler, P. 2001. Technological innovation and initial public offerings. Review of Financial Studies 14(2), 459-94.

Mayers, S.C., Majluf, N.S. 1984. Corporate financing and investment decisions: When firms have information that investors do not have. Journal of Financial Economics 13(2), 187-221.

Merton, R.C., Bodie, Z. 2004. The design of financial systems: Towards a synthesis of function and structure. Working Paper 10620, National Bureau of Economic Research.

Michelacci, C., Suarez, J. 2004. Business creation and the stock market. Review of Economic Studies 71, 459-81.

Morck, R, Nakamura, M. 1999. Banks and corporate control in Japan. Journal of Finance 54, 319-40.

OECD. 2006. Purchasing power parities. Report, ww.oecd.org/std/ppp.

Ofek, E., Richardson, M. 2002. The valuation and market rationality of Internet stock prices. Oxford Review of Economic Policy 18(3), 265-87.

Oxera. 2006. The cost of capital: An international comparison. Report, www.cityoflondon.gov.uk/Corporation/business_city/research_statistics/research_pub lications.htm

Pagano, M., Panetta, F., Zingales, L. 1998. Why do companies go public? An empirical analysis. Journal of Finance 53(1), 27-64.

Posner, E. 2005. Sources of institutional change: The supranational origins of Europe's new stock markets. World Politics 58, 1-40.

Preissl, B. 2000. Service innovation: what makes it different? Empirical evidence from Germany. In Metcalfe, J.S., Miles, I. (Eds) Innovation Systems in the Service Economy. Measurement and Case Study Analysis. Kluwer, Boston, 125-48. 
Rajan, R.G., Zingales, L. 1995. What do we know about capital structure? Some evidence from international data. Journal of Finance 50(5), 1421-1460.

Ritter, J., Welch, I. 2002. A review of IPO activity, pricing, and allocations. Journal of Finance 57, 1795-828.

Röell, A. 1996. The decision to go public: An overview. European Economic Review 40, 1071-81.

Schumpeter, J.A. 1934. The Theory of Economic Development. Harvard University Press, Cambridge, MA.

Shleifer, A., Vishny, R.W. 1997. A survey of corporate governance. Journal of Finance 52(2), 737-83.

Sirilli, G., Evangelista, R. 1998. Technological innovation in services and manufacturing: Results from Italian surveys. Research Policy 27, 881-899.

Subrahmanyam, A., Titman, S. 1999. The going-public decision and the development of financial markets. Journal of Finance 54(3), 1045-82.

Teece, D.J. 2003. Expert talent and the design of professional services firms. Industrial and Corporate Change 12(4), 895-916.

Tether, B.S. 2003. The sources and aims of innovation in services: variety between and within sectors. Economics of Innovation and New Tehchnology 12(6), 481-505.

Titman, S. 1984. The effects of capital structure on the firm's liquidation decision. Journal of Financial Economics 13, 137-151.

Van Nordenflycht, A. 2007. Is public ownership bad for professional service firms? Ad agency ownership, performance, and creativity. Academy of Management Journal 50(2), 429-45.

Weinstein, D.E., Yafeh, Y. 1998. On the costs of a bank-centered financial system: Evidence from the changing main bank relations in Japan. Journal of Finance 53, 635-72.

Wood, P. (Ed) 2002. Consultancy and Innovation: The Business Service Revolution in Europe. London: Routledge. 


\section{Table 1. Large firms, publicly traded firms, and stock market participation by country}

The table shows the number of large firms, and publicly traded firms by country, as well as their division between manufacturing $(\mathrm{M})$ and services $(\mathrm{S})$. Large firms are defined as those with turnover exceeding $€ 50 \mathrm{~m}$, where $€ 50 \mathrm{~m}$ is adjusted to the price level of the country. SMP is calculated as the ratio of the number of publicly traded companies to the number of large companie. EU Transition group consists of: Bulgaria, Czech Republic, Estonia, Hungary, Latvia, Lithuania, Poland, Romania, Slovakia, and Slovenia. Europe non-transition stands for the remaining 20 European countries. Source: ORBIS.

\begin{tabular}{|c|c|c|c|c|c|c|c|c|c|c|}
\hline & \multicolumn{4}{|c|}{ Large firms } & \multicolumn{4}{|c|}{ Publicly traded firms } & \multirow{2}{*}{\multicolumn{2}{|c|}{ SMP }} \\
\hline & \multicolumn{2}{|c|}{ Number } & \multicolumn{2}{|c|}{ Share } & \multicolumn{2}{|c|}{ Number } & \multicolumn{2}{|c|}{ Share } & & \\
\hline & M & S & $\mathrm{M}$ & $\mathrm{S}$ & M & $\mathrm{S}$ & M & S & M & S \\
\hline Austria & 328 & 555 & 37 & 63 & 36 & 66 & 35 & 65 & 0.11 & 0.12 \\
\hline Belgium & 601 & 1,227 & 33 & 67 & 58 & 84 & 41 & 59 & 0.10 & 0.07 \\
\hline Bulgaria & 46 & 137 & 25 & 75 & 194 & 122 & 61 & 39 & 4.22 & 0.89 \\
\hline Cyprus & 3 & 19 & 14 & 86 & 24 & 97 & 20 & 80 & 8.00 & 5.11 \\
\hline Czech Republic & 541 & 838 & 39 & 61 & 10 & 11 & 48 & 52 & 0.02 & 0.01 \\
\hline Denmark & 222 & 845 & 21 & 79 & 55 & 112 & 33 & 67 & 0.25 & 0.13 \\
\hline Estonia & 33 & 99 & 25 & 75 & 8 & 5 & 62 & 38 & 0.24 & 0.05 \\
\hline Finland & 349 & 519 & 40 & 60 & 72 & 59 & 55 & 45 & 0.21 & 0.11 \\
\hline France & 2,175 & 4,889 & 31 & 69 & 322 & 584 & 36 & 64 & 0.15 & 0.12 \\
\hline Germany & 2,727 & 5,608 & 33 & 67 & 363 & 599 & 38 & 62 & 0.13 & 0.11 \\
\hline Greece & 221 & 332 & 40 & 60 & 159 & 134 & 54 & 46 & 0.72 & 0.40 \\
\hline Hungary & 170 & 296 & 36 & 64 & 16 & 17 & 48 & 52 & 0.09 & 0.06 \\
\hline Iceland & 8 & 31 & 21 & 79 & 8 & 12 & 40 & 60 & 1.00 & 0.39 \\
\hline Ireland & 439 & 1,265 & 26 & 74 & 25 & 67 & 27 & 73 & 0.06 & 0.05 \\
\hline Italy & 2,480 & 3,448 & 42 & 58 & 124 & 132 & 48 & 52 & 0.05 & 0.04 \\
\hline Japan & 3,429 & 7,863 & 30 & 70 & 1,674 & 1,935 & 46 & 54 & 0.49 & 0.25 \\
\hline Latvia & 23 & 90 & 20 & 80 & 19 & 13 & 59 & 41 & 0.83 & 0.14 \\
\hline Lithuania & 43 & 74 & 37 & 63 & 19 & 17 & 53 & 47 & 0.44 & 0.23 \\
\hline Luxembourg & 35 & 201 & 15 & 85 & 8 & 32 & 20 & 80 & 0.23 & 0.16 \\
\hline Malta & 9 & 20 & 31 & 69 & 0 & 7 & 0 & 100 & 0.00 & 0.35 \\
\hline Netherlands & 805 & 2,132 & 27 & 73 & 73 & 144 & 34 & 66 & 0.09 & 0.07 \\
\hline Norway & 227 & 521 & 30 & 70 & 61 & 179 & 25 & 75 & 0.27 & 0.34 \\
\hline Poland & 762 & 942 & 45 & 55 & 113 & 100 & 53 & 47 & 0.15 & 0.11 \\
\hline Portugal & 225 & 537 & 30 & 70 & 25 & 40 & 38 & 62 & 0.11 & 0.07 \\
\hline Romania & 250 & 281 & 47 & 53 & 49 & 14 & 78 & 22 & 0.20 & 0.05 \\
\hline Slovakia & 120 & 253 & 32 & 68 & 102 & 114 & 47 & 53 & 0.85 & 0.45 \\
\hline Slovenia & 91 & 98 & 48 & 52 & 45 & 31 & 59 & 41 & 0.49 & 0.32 \\
\hline Spain & 1,252 & 2,296 & 35 & 65 & 69 & 95 & 42 & 58 & 0.06 & 0.04 \\
\hline Sweden & 458 & 1,191 & 28 & 72 & 130 & 244 & 35 & 65 & 0.28 & 0.20 \\
\hline Switzerland & 334 & 839 & 28 & 72 & 115 & 145 & 44 & 56 & 0.34 & 0.17 \\
\hline UK & 2,461 & 7,537 & 25 & 75 & 548 & 1,702 & 24 & 76 & 0.22 & 0.23 \\
\hline USA & 8,233 & 23,733 & 26 & 74 & 2,968 & 5,312 & 36 & 64 & 0.36 & 0.22 \\
\hline Europe non-transition & 15,364 & 34,018 & 31 & 69 & 2,275 & 4,536 & 33 & 67 & 0.15 & 0.13 \\
\hline EU Transition & 2,079 & 3,108 & 40 & 60 & 575 & 444 & 56 & 44 & 0.28 & 0.14 \\
\hline Total sample & 29,105 & 68,722 & 30 & 70 & 7,492 & 12,227 & 38 & 62 & 0.26 & 0.18 \\
\hline
\end{tabular}




\section{Table 2. Stock market participation by country and group of activities}

This table shows stock market participation rates by country and group of activities according to OECD/Eurostat classification. For manufacturing: LT-low technology, MLT-medium low technology, MHT-medium high technology, HT-high technology; for services: HTKI-high technology knowledge intensive, OKI-other knowledge intensive, LKI-less knowledge intensive. SMP rates are not available for countries where there are no large firms in a given group of activities.

\begin{tabular}{lrrrrrrr}
\hline & \multicolumn{3}{c}{ Manufacturing } & \multicolumn{3}{c}{ Services } \\
& HT & MHT & MLT & LT & HTKI & OKI & LKI \\
\hline Austria & 0.14 & 0.13 & 0.11 & 0.09 & 0.54 & 0.23 & 0.02 \\
Belgium & 0.46 & 0.09 & 0.07 & 0.08 & 0.36 & 0.11 & 0.01 \\
Bulgaria & 1.50 & 4.73 & 3.54 & 5.00 & 1.00 & 1.44 & 0.61 \\
Cyprus & NA & NA & NA & 4.67 & 4.00 & 5.50 & 4.75 \\
Czech Republic & 0.00 & 0.02 & 0.01 & 0.02 & 0.04 & 0.05 & 0.00 \\
Denmark & 0.42 & 0.26 & 0.20 & 0.21 & 0.36 & 0.17 & 0.03 \\
Estonia & 0.00 & 0.30 & 0.00 & 0.33 & 0.33 & 0.06 & 0.03 \\
Finland & 0.57 & 0.14 & 0.16 & 0.21 & 0.48 & 0.19 & 0.02 \\
France & 0.44 & 0.12 & 0.13 & 0.13 & 0.72 & 0.12 & 0.06 \\
Germany & 0.32 & 0.12 & 0.09 & 0.12 & 0.59 & 0.12 & 0.04 \\
Greece & 1.08 & 0.38 & 0.79 & 0.82 & 1.15 & 0.80 & 0.22 \\
Hungary & 0.00 & 0.20 & 0.03 & 0.09 & 0.18 & 0.14 & 0.01 \\
Iceland & 1.00 & 1.00 & NA & 1.00 & 0.67 & 0.47 & 0.18 \\
Ireland & 0.05 & 0.07 & 0.14 & 0.03 & 0.12 & 0.07 & 0.02 \\
Italy & 0.09 & 0.05 & 0.04 & 0.05 & 0.15 & 0.06 & 0.01 \\
Japan & 0.58 & 0.52 & 0.42 & 0.45 & 0.81 & 0.32 & 0.18 \\
Latvia & NA & 2.25 & 0.33 & 0.56 & 0.25 & 0.25 & 0.11 \\
Lithuania & 0.50 & 0.56 & 0.20 & 0.44 & 0.33 & 0.64 & 0.12 \\
Luxembourg & 0.50 & 0.33 & 0.16 & 0.40 & 0.40 & 0.19 & 0.04 \\
Malta & 0.00 & 0.00 & 0.00 & 0.00 & 0.25 & 0.50 & 0.17 \\
Netherlands & 0.21 & 0.08 & 0.07 & 0.08 & 0.21 & 0.11 & 0.02 \\
Norway & 0.82 & 0.29 & 0.12 & 0.20 & 1.35 & 0.44 & 0.09 \\
Poland & 0.19 & 0.10 & 0.21 & 0.14 & 0.58 & 0.17 & 0.05 \\
Portugal & 0.00 & 0.06 & 0.09 & 0.18 & 0.30 & 0.10 & 0.04 \\
Romania & 0.00 & 0.33 & 0.29 & 0.06 & 0.00 & 0.16 & 0.03 \\
Slovakia & 2.00 & 0.68 & 0.66 & 1.06 & 1.80 & 0.85 & 0.20 \\
Slovenia & 0.00 & 0.38 & 0.42 & 0.74 & 0.20 & 0.37 & 0.30 \\
Spain & 0.03 & 0.03 & 0.05 & 0.08 & 0.05 & 0.08 & 0.02 \\
Sweden & 0.81 & 0.26 & 0.27 & 0.19 & 0.85 & 0.18 & 0.11 \\
Switzerland & 0.44 & 0.36 & 0.42 & 0.24 & 0.32 & 0.22 & 0.07 \\
UK & 0.57 & 0.22 & 0.22 & 0.15 & 0.51 & 0.30 & 0.09 \\
USA & 0.87 & 0.41 & 0.16 & 0.21 & 0.81 & 0.25 & 0.10 \\
Europe non-transition & 0.38 & 0.13 & 0.12 & 0.13 & 0.48 & 0.17 & 0.05 \\
EU transition & 0.18 & 0.26 & 0.27 & 0.31 & 0.42 & 0.31 & 0.07 \\
\hline & & & & & & &
\end{tabular}




\section{Figure 1. Innovativeness and stock market participation}

This figure depicts selected data from table 2 for manufacturing (left) and services (right). It relates the decreasing level of innovativeness based on the OECD/Eurostat classification (axis $\mathrm{x}$ ) to SMP rate (axis $\mathrm{y}$ ).
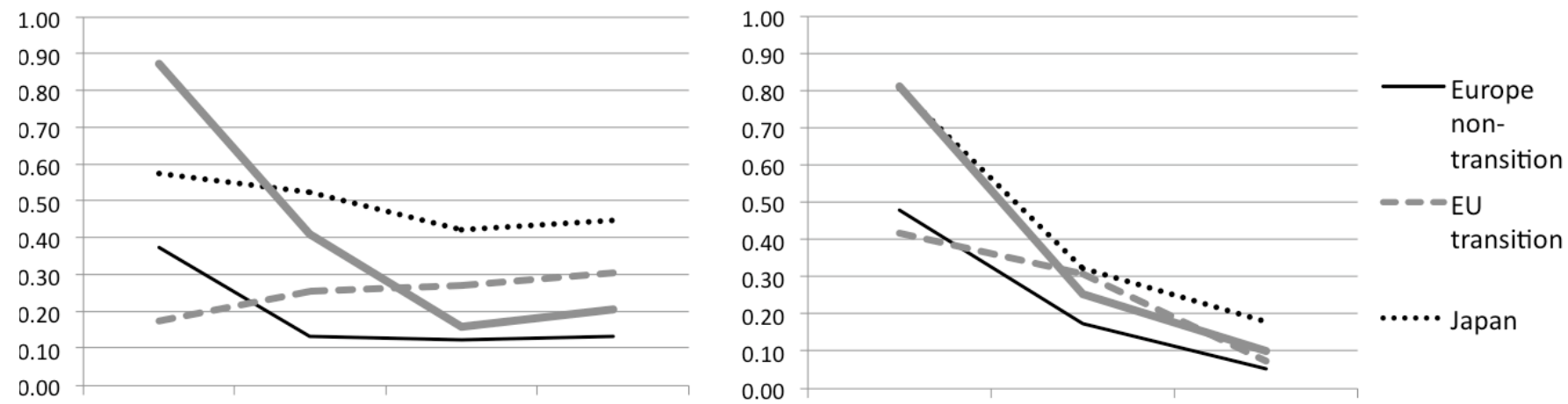

$\begin{array}{lll}\text { HT } & \text { MHT }\end{array}$

HTKI OKI LKI

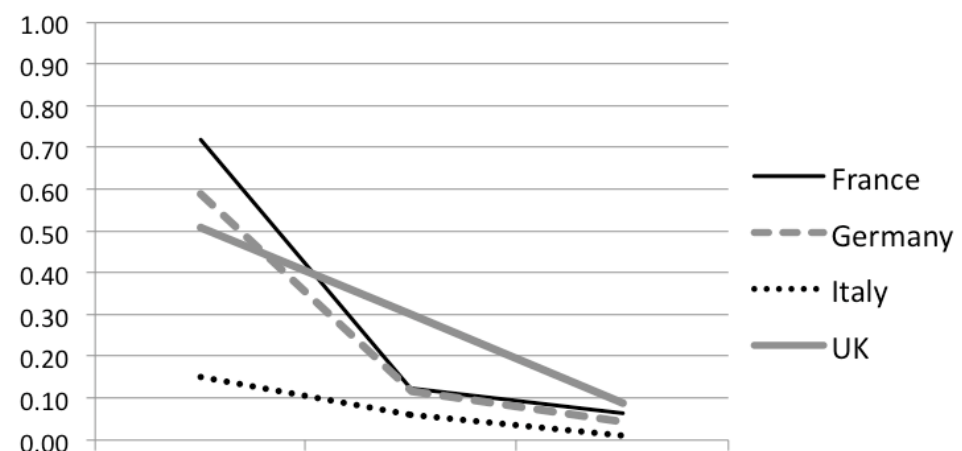

HT $\quad$ MHT $\quad$ MLT LT
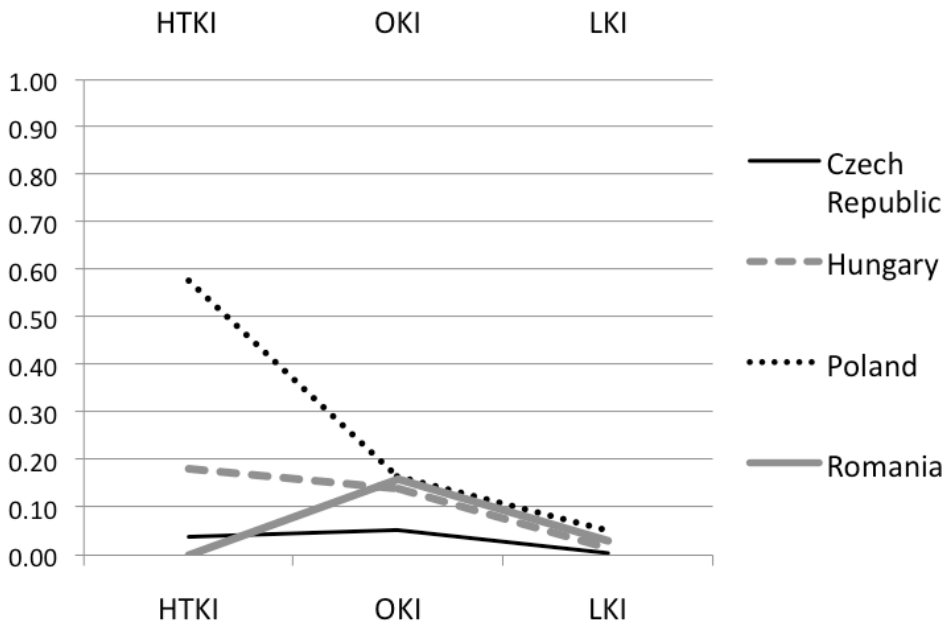
Table 3. Regression of stock market participation on sector and country variables

The table reports results of an OLS regression for non-transition countries. Independent variables are presented in appendix 2 and 3. Country dummies have been included in each equation but are not reported. Coefficients are significant at $10 \%(*), 5 \%(* *)$, and $1 \%(* * *)$ level according to t-statistics. $\mathrm{F}$ is significant for each equation at the level of $0.1 \%$.

\begin{tabular}{|c|c|c|c|c|c|c|c|c|c|c|c|c|c|c|c|c|c|c|}
\hline & (1) & & (2) & & (3) & & (4) & & (5) & & (6) & & (7) & & (8) & & (9) & \\
\hline \multicolumn{19}{|c|}{ Manufacturing } \\
\hline I & 0.050 & $* * *$ & 0.053 & $* * *$ & 0.053 & $* * *$ & & & -0.565 & $* * *$ & & & 0.086 & $* * *$ & & & -0.526 & $* * *$ \\
\hline Size & & & -0.002 & $* *$ & -0.002 & $* *$ & -0.002 & $* *$ & -0.002 & $* *$ & -0.002 & $* *$ & -0.002 & $* * *$ & -0.002 & $* * *$ & -0.002 & $* * *$ \\
\hline Share & & & & & -0.004 & & -0.004 & & -0.004 & & -0.008 & $* * *$ & -0.008 & $* * *$ & -0.008 & $* * *$ & -0.008 & $* * *$ \\
\hline I*LRE & & & & & & & 0.001 & $* * *$ & 0.007 & $* * *$ & & & & & 0.001 & $* * *$ & 0.007 & $* * *$ \\
\hline I*IBoom & & & & & & & & & & & 0.000 & $* *$ & 0.001 & & 0.000 & * & 0.000 & \\
\hline $\mathrm{N}$ & 422 & & 422 & & 422 & & 422 & & 422 & & 410 & & 410 & & 410 & & 410 & \\
\hline $\mathrm{F}$ & 19.3 & & 18.9 & & 18.2 & & 18.4 & & 18.6 & & 11.3 & & 11.8 & & 12.0 & & 12.1 & \\
\hline R sq. & 0.515 & & 0.522 & & 0.524 & & 0.527 & & 0.539 & & 0.379 & & 0.401 & & 0.406 & & 0.418 & \\
\hline \multicolumn{19}{|l|}{ Services } \\
\hline I & 0.210 & $* * *$ & 0.238 & $* * *$ & 0.222 & $* * *$ & & & 0.044 & & & & 0.325 & $* * *$ & & & 0.799 & $*$ \\
\hline Size & & & -0.006 & $* * *$ & -0.006 & $* * *$ & -0.006 & $* * *$ & -0.006 & $* * *$ & -0.004 & $* * *$ & -0.005 & $* * *$ & -0.004 & $* * *$ & -0.005 & $* * *$ \\
\hline Share & & & & & -0.011 & $*$ & -0.011 & $* *$ & -0.011 & $* *$ & -0.010 & $* * *$ & -0.009 & $* * *$ & -0.009 & $* * *$ & -0.009 & $* * *$ \\
\hline I*LRE & & & & & & & 0.002 & $* * *$ & 0.002 & & & & & & 0.003 & $* * *$ & -0.005 & \\
\hline I*IBoom & & & & & & & & & & & 0.004 & $* * *$ & -0.002 & * & -0.002 & & -0.003 & $* *$ \\
\hline $\mathrm{N}$ & 447 & & 447 & & 447 & & 447 & & 447 & & 417 & & 417 & & 417 & & 417 & \\
\hline $\mathrm{F}$ & 17.9 & & 18.3 & & 17.9 & & 17.9 & & 17.2 & & 5.0 & & 6.7 & & 6.5 & & 6.4 & \\
\hline R sq. & 0.482 & & 0.498 & & 0.505 & & 0.505 & & 0.505 & & 0.209 & & 0.271 & & 0.268 & & 0.273 & \\
\hline
\end{tabular}


Appendix 1. Publicly traded companies by country at the end of September 2006

For each country the appendix gives the total number of publicly traded companies, and a description of stock market segments included. Firms in agriculture, mining, utilities, and construction are excluded. The data were obtained from ORBIS by the BVDEP, and their consistency was tested by comparison to data from the World Federation of Exchanges, the Federation of European Stock Exchanges, and the websites of individual stock exchanges. In addition to the domestic segments stated, for each country the numbers include companies that are publicly traded only on a foreign exchange (for example the Irish companies traded on the Alternative Investment Market (AIM) of the London Stock Exchange, but not traded on the Irish Stock Exchange).

\begin{tabular}{|c|c|c|}
\hline Austria & 102 & Prime and Standard segment of the Wiener Börse \\
\hline Belgium & 142 & Eurolist and Marché Libre of the Euronext Brussels \\
\hline Bulgaria & 316 & $\begin{array}{l}\text { All companies listed on the Official and Unofficial Market of the } \\
\text { Bulgarian Stock Exchange }\end{array}$ \\
\hline Cyprus & 121 & All companies listed on the Cyprus Stock Exchange \\
\hline Czech Republic & 21 & All companies listed on the Prague Stock Exchange \\
\hline Denmark & 167 & $\begin{array}{l}\text { All companies listed on the OMX Copenhagen and the First North } \\
\text { Exchange }\end{array}$ \\
\hline Estonia & 13 & All companies listed on the OMX Tallin \\
\hline Finland & 131 & All companies listed on OMX Helsinki. \\
\hline France & 906 & Eurolist, Alternext, and Marché Libre of the Euronext Paris \\
\hline Germany & 962 & $\begin{array}{l}\text { Official Market and the Open Market (Freiverkehr i.e. the } \\
\text { Regulated Unofficial market) of the Deutsche Börse. }\end{array}$ \\
\hline Greece & 293 & $\begin{array}{l}\text { Big cap, mid and small cap, special financial character, and under } \\
\text { surveillance companies at the Athens Stock Echange, but not } \\
\text { suspended listed companies. }\end{array}$ \\
\hline Hungary & 33 & $\begin{array}{l}\text { All companies with equities category A or B traded on the } \\
\text { Budapest Stock Exchange }\end{array}$ \\
\hline Iceland & 20 & All companies listed on the Iceland Stock Exchange \\
\hline Ireland & 92 & $\begin{array}{l}\text { The Official List and the Irish Enterprise Exchange (IEX) of the } \\
\text { Irish Stock Exchange. }\end{array}$ \\
\hline Italy & 256 & $\begin{array}{l}\text { All segments of the Borsa Italiana i.e. Blue Chip, Star, Standard, } \\
\text { and Mercato Expandi }\end{array}$ \\
\hline Latvia & 32 & All companies listed on the OMX Riga \\
\hline Lithuania & 36 & All companies listed on the OMX Vilnius \\
\hline Luxembourg & 40 & All companies listed on the Luxembourg Stock Exchange \\
\hline Malta & 7 & $\begin{array}{l}\text { All companies listed on the official list of the Malta Stock } \\
\text { Exchange }\end{array}$ \\
\hline Netherlands & 217 & All companies listed at Euronext Amsterdam \\
\hline Norway & 240 & $\begin{array}{l}\text { All segments of the Oslo Stock Exchange i.e. OBX, OB Match, OB } \\
\text { Standard, and OB New. }\end{array}$ \\
\hline Poland & 213 & $\begin{array}{l}\text { All companies listed on the Main and the Parallel Market of the } \\
\text { Warsaw Stock Exchange }\end{array}$ \\
\hline Portugal & 65 & All companies listed on the Euronext Lisbon \\
\hline Romania & 63 & All companies listed on the Bucharest Stock Exchange \\
\hline Slovakia & 216 & All companies with shares traded on the Bratislava Stock Exchange \\
\hline Slovenia & 76 & $\begin{array}{l}\text { All companies on the Official and Semi-Official Market of the } \\
\text { Ljubljana Stock Exchange }\end{array}$ \\
\hline Spain & 164 & $\begin{array}{l}\text { Companies traded on the Continuous Market and the Floor of the } \\
\text { Bolsas y Mercados Españoles (BME-X). SICAVs and SIMs are not } \\
\text { included. }\end{array}$ \\
\hline
\end{tabular}




\begin{tabular}{|l|c|l|}
\hline Sweden & 374 & $\begin{array}{l}\text { All companies listed on the OMX Stockholm, the Nordic Growth } \\
\text { Market, and the First North Exchange }\end{array}$ \\
\hline Switzerland & 260 & $\begin{array}{l}\text { Main Market, Local Caps, Real Estate Companies and Investment } \\
\text { Companies of the SWX Swiss Exchange. }\end{array}$ \\
\hline UK & 2250 & $\begin{array}{l}\text { All companies listed on the London Stock Exchange, including the } \\
\text { AIM }\end{array}$ \\
\hline Japan & 3609 & $\begin{array}{l}\text { All companies traded on the Tokyo Stock Exchange, the JASDAQ, } \\
\text { the Nagoya SE, the Osaka Securities Exchange, the Sapporo Stock } \\
\text { Exchange, and the OTC Japan }\end{array}$ \\
\hline USA & 8280 & $\begin{array}{l}\text { The New York Stock Exchange, the NASDAQ National Market, } \\
\text { the NASDAQ Bulletin Board, the American Stock Exchange, and } \\
\text { other OTC markets }\end{array}$ \\
\hline
\end{tabular}

\section{Appendix 2. NACE codes, the OECD/Eurostat classification and other data by sector}

The appendix presents economic sectors and their NACE Rev.1.1. codes, as used within the European Union, as well as their OECD/Eurostat classification based on R\&D intensity (Eurostat 2006). SMP reports the ratio of the number of publicly traded companies to the number of all large companies in a given sector, calculated on the basis of ORBIS database provided by the BVDEP. Size is the median turnover $(€ \mathrm{~m})$ of all firms in a sector across all 32 countries for which data are available in ORBIS. The appendix presents only these sectors for which at least one company with turnover exceeding $€ 50 \mathrm{~m}$ is recorded in the sample countries. This implies that categories: private households (code P95), undifferentiated goods (P96), undifferentiated services (P97), and extra-territorial organisations (Q99) are omitted. Key for the names of $\mathrm{OECD} /$ Eurostat groups of activities can be found at table 2.

\begin{tabular}{|l|l|r|r|c|}
\hline NACE & Sector name & SMP & Size & $\begin{array}{l}\text { OECD/ } \\
\text { Eurostat }\end{array}$ \\
\hline DA15 & Manufacture of food products and beverages & 0.15 & 33 & \\
DA16 & Manufacture of tobacco products & 0.22 & 90 & \\
DB17 & Manufacture of textiles & 0.34 & 22 & \\
DB18 & Manufacture of wearing apparel & 0.35 & 17 & \multirow{2}{*}{ LT } \\
DC19 & Tanning and dressing of leather & 0.36 & 20 & \\
DD20 & Manufacture of wood and cork & 0.15 & 24 & \\
DE21 & Manufacture of pulp and paper & 0.16 & 34 & \\
DE22 & Publishing and printing & 0.20 & 27 & \\
\hline DF23 & Manufacture of coke, refined petroleum products, and nuclear fuel & 0.16 & 62 & MLT \\
\hline DG24 & Manufacture of chemicals and chemical products & 0.34 & 42 & MHT \\
\hline DH25 & Manufacture of rubber and plastic products & 0.16 & 27 & \\
DI26 & Manufacture of other non-metallic mineral products & 0.20 & 26 & \multirow{2}{*}{ MLT } \\
DJ27 & Manufacture of basic metals & 0.22 & 41 & \\
DJ28 & Manufacture of metal products & 0.16 & 24 & \\
\hline DK29 & Manufacture of machinery & 0.25 & 30 & MHT \\
\hline DL30 & Manufacture of office machinery and computers & 0.57 & 36 & HT \\
\hline DL31 & Manufacture of electrical machinery & 0.26 & 30 & MHT \\
\hline DL32 & Manufacture of radio, television, and communication eq. and app. & 0.65 & 36 & \multirow{2}{*}{ HT } \\
\hline DL33 & Manufacture of medical, precision, and optical instruments & 0.58 & 29 & \\
\hline DM34 & Manufacture of motor vehicles & 0.16 & 47 & \multirow{2}{*}{ MHT } \\
DM35 & Manufacture of other transport equipment & 0.22 & 35 & \\
\hline DN36 & Manufacture of furniture & 0.28 & 24 & \multirow{2}{*}{ LT } \\
DN37 & Recycling & 0.02 & 25 & \\
\hline
\end{tabular}




\begin{tabular}{|l|l|r|r|r|}
\hline $\begin{array}{l}\text { NACE } \\
\text { code }\end{array}$ & Sector name & SMP & Size & \multicolumn{1}{l|}{$\begin{array}{l}\text { OECD/ } \\
\text { Eurostat }\end{array}$} \\
\hline G50 & Sale, maintenance, and repair of motor vehicles & 0.03 & 27 & \\
G51 & Wholesale and commission trade & 0.06 & 29 & \\
G52 & Retail trade; repair of personal and household goods & 0.15 & 27 & LKI \\
H55 & Hotels and restaurants & 0.31 & 13 & \\
I60 & Land transport; transport via pipelines & 0.13 & 22 & \\
\hline I61 & Water transport & 0.21 & 31 & \multirow{2}{*}{ OKI } \\
I62 & Air transport & 0.18 & 59 & \\
\hline I63 & Supporting transport activities; travel agencies & 0.10 & 27 & LKI \\
\hline I64 & Post and telecommunications & 0.50 & 32 & HTKI \\
\hline J65 & Financial intermediation, except insurance and pension funding & 0.37 & 13 & \\
J66 & Insurance and pension funding, except compulsory social security & 0.06 & 104 & \\
J67 & Activities auxiliary to financial intermediation & 0.80 & 21 & OKI \\
K70 & Real estate activities & 0.20 & 13 & \\
K71 & Renting of machinery and equipment & 0.17 & 27 & \\
\hline K72 & Computer and related activities & 0.75 & 26 & \multirow{2}{*}{ HTKI } \\
K73 & Research and development & 0.54 & 20 & \\
\hline K74 & Other business activities & 0.15 & 23 & OKI \\
\hline L75 & Public administration and defense; compulsory social security & 0.04 & 15 & LKI \\
\hline M80 & Education & 0.44 & 19 & \multirow{2}{*}{ OKI } \\
N85 & Health and social work & 0.09 & 18 & \\
\hline O90 & Sewage and refuse disposal & 0.22 & 22 & LKI \\
O91 & Activities of membership organisations & 0.02 & 18 & \\
\hline O92 & Recreational, cultural and sporting activities & 0.29 & 25 & OKI \\
\hline O93 & Other service activities & 0.20 & 18 & LKI \\
\hline
\end{tabular}

\section{Appendix 3. Data by country and descriptive statistics for multivariate analysis}

Panel A presents data on legal and regulatory environment ( $L R E)$ and Internet boom (IBoom) by country. $L R E$ is calculated as the average of the World Bank governance indicators of the rule of law, and regulatory quality for 1996, 1998, 2000, 2002, 2004, and 2006. In other words, it is the average of 12 figures ( 2 indicators at 6 points in time), where each figure represents the percentile rank of a country according to a given indicator in a given year. IBoom is calculated as the ratio of the number of IPOs by domestic firms between the start of 1998 and the end of 2000 to the number of domestic firms listed at the end of 1997, expressed in percentage terms.

Panel B shows descriptive statistics on $S M P$ and the share of a sector in the total number of manufacturing or services (Share). SMP is calculated as the ratio of the number of publicly traded companies in a given sector of a given country to the number of all companies with turnover exceeding $€ 50 \mathrm{~m}$, where $€ 50 \mathrm{~m}$ is adjusted to the price level of the country. Share stands for the share of a given sector in a given country in the total number of firms in manufacturing and services respectively. 
Panel A

\begin{tabular}{|c|c|c|}
\hline Country & LRE & IBoom \\
\hline Austria & 95.0 & 12.9 \\
\hline Belgium & 89.0 & 30.4 \\
\hline Bulgaria & 56.0 & NA \\
\hline Cyprus & 82.5 & NA \\
\hline Czech Republic & 77.0 & NA \\
\hline Denmark & 97.5 & 10.1 \\
\hline Estonia & 80.5 & NA \\
\hline Finland & 97.5 & 46.8 \\
\hline France & 85.5 & 56.1 \\
\hline Germany & 93.0 & 51.4 \\
\hline Greece & 75.5 & 53.3 \\
\hline Hungary & 78.5 & NA \\
\hline Iceland & 92.0 & NA \\
\hline Ireland & 95.0 & 16.9 \\
\hline Italy & 75.5 & 43.4 \\
\hline Japan & 82.5 & 14.0 \\
\hline Latvia & 70.0 & NA \\
\hline Lithuania & 71.0 & NA \\
\hline Luxembourg & 97.0 & 16.1 \\
\hline Malta & 84.0 & NA \\
\hline Netherlands & 96.5 & 24.1 \\
\hline Norway & 94.0 & 26.0 \\
\hline Poland & 69.0 & NA \\
\hline Portugal & 85.0 & 12.8 \\
\hline Romania & 51.0 & NA \\
\hline Slovakia & 67.5 & NA \\
\hline Slovenia & 79.0 & NA \\
\hline Spain & 87.0 & 114.8 \\
\hline Sweden & 94.5 & 50.2 \\
\hline Switzerland & 97.0 & 26.4 \\
\hline UK & 96.5 & 34.0 \\
\hline USA & 93.5 & 26.7 \\
\hline
\end{tabular}

Panel B

\begin{tabular}{|c|c|c|c|c|c|c|}
\hline \multirow{2}{*}{\multicolumn{7}{|c|}{$\begin{array}{cc}\text { No. of cases } & \text { Min } \\
\text { Manufacturing in non-transition countries }\end{array}$}} \\
\hline & & & & & & \\
\hline SMP & 422 & 0 & 4 & 0.27 & 0.14 & 0.41 \\
\hline Share & 422 & 0.03 & 66.67 & 5.21 & 3.29 & 6.76 \\
\hline \multicolumn{7}{|c|}{ Manufacturing in transition countries } \\
\hline SMP & 184 & 0 & 15 & 0.72 & 0.14 & 1.86 \\
\hline Share & 184 & 0.26 & 39.53 & 5.43 & 3.77 & 5.95 \\
\hline \multicolumn{7}{|c|}{ Services in non-transition countries } \\
\hline SMP & 447 & 0 & 13 & 0.38 & 0.12 & 0.96 \\
\hline Share & 162 & 0.01 & 42.77 & 4.92 & 2.16 & 7.35 \\
\hline \multicolumn{7}{|c|}{ Services in transition countries } \\
\hline SMP & 447 & 0 & 12 & 0.45 & 0.06 & 1.37 \\
\hline Share & 162 & 0.11 & 58.11 & 6.17 & 2.43 & 10.29 \\
\hline
\end{tabular}

